\title{
Milk-clotting properties on bovine caseins of a novel cysteine peptidase from germinated Moringa oleifera seeds
}

\author{
Xuefeng Wang, ${ }^{1} \odot$ Qiong Zhao, ${ }^{1} \odot \mathrm{Li} \mathrm{He},{ }^{1}$ Yanan Shi, ${ }^{1}$ Jiangping Fan, ${ }^{1}$ Yue Chen, ${ }^{2 *}$ and Aixiang Huang ${ }^{1 *} \odot$ \\ ${ }_{1}^{1}$ College of Food Science and Technology, Yunnan Agricultural University, Kunming 650201, Yunnan, China \\ ${ }^{2}$ Biotechnology and Germplasm Resources Institute, Yunnan Academy of Agricultural Sciences, Kunming 650205, Yunnan, China
}

\section{ABSTRACT}

A cysteine peptidase was previously identified from germinated Moringa oleifera seeds, but its milk-clotting properties on bovine caseins was still unclear. In this study, this novel cysteine peptidase (MoCP) showed preferential activity on $\kappa$-casein $(\kappa-\mathrm{CN})$, with greater hydrolytic activity compared with calf rennet, whereas weak hydrolysis of $\alpha$-casein and $\beta$-casein made MoCP suitable for application in cheesemaking and may yield various functional peptides. All 3 evaluated caseins were hydrolyzed to form relatively stable peptide bands within $3 \mathrm{~h}$ of proteolysis with MoCP. Cleavage sites were determined by gel electrophoresis, liquid chromatography mass spectrometry/mass spectrometry, and peptide sequencing, which revealed that cleavage of $\kappa$-CN by MoCP occurred at residue Ile129-Pro130 and generated a 14,895.37-Da peptide. The flocculation reaction between $\mathrm{MoCP}$ and $\kappa-\mathrm{CN}$ determined by 3-dimensional microscopy with super-depth of field revealed that the initial $30 \mathrm{~min}$ of reaction were key for milk coagulation, which may affect curd yield. Overall, the findings presented herein suggest that the cysteine peptidase from germinated $M$. oleifera seeds can be considered a promising plant-derived rennet alternative for use in cheese manufacture.

Key words: germinated Moringa oleifera seed, cysteine peptidase, $\kappa$-casein, cleavage site, flocculation reaction

\section{INTRODUCTION}

Coagulation of milk is one of the key steps in cheese manufacture, and milk-clotting enzymes play an important role in this process. Rennet is the most widely used complex of milk-clotting enzymes in cheesemaking, which is obtained from the abomasum of unweaned calves (Alihanoğlu et al., 2018) and whose main com-

\footnotetext{
Received October 12, 2021.

Accepted January 1, 2022.

*Corresponding authors: 358455454@qq.com and aixianghuang@ 126.com
}

ponent is the protease chymosin. However, the worldwide increasing demand for cheese, ethical or religious restrictions regarding the use of calf rennet (Narwal et al., 2016; Salehi et al., 2017), and the import regulations for chymosin in China have prompted the search for new rennet alternatives with selective milk-clotting properties. Most plant proteases are active over wide ranges of temperatures, $\mathrm{pH}$, surfactants, solvents, and denaturing agents (Afsharnezhad et al., 2019). These enzymes are found in almost all kinds of plant tissues and can be obtained from their natural source or through in vitro culture to ensure a continuous supply of plant proteases, and it appears to be a general rule that all proteolytic enzymes have the ability to clot milk under appropriate conditions (González-Rábade et al., 2011). Recently, plant-derived milk-clotting proteases, including papain and bromelain, have demonstrated potential for application in cheese manufacture because of the abundance of plant resources and the technical feasibility of the extraction process (Jacob et al., 2011; Shah et al., 2014).

Moringa oleifera grows widely in tropical and subtropical regions, and is considered as edible for human consumption and livestock feed in many countries such as India, Pakistan, Philippines, China and Senegal (Leone et al., 2016). Moringa oleifera is well known for its high protein, calcium, and vitamin content, as well as for its nutritional and health properties (Saini et al., 2016; Falowo et al., 2018). Germination of plant seeds can improve the activity of plant proteases for the mobilization of proteins stored in the seed, which thus serve as the main source of nutrients, and certain plant proteases with hydrolytic activity can potentially be used as industrial biomaterials (Simpson, 2001; Dong et al., 2015; Szewińska et al., 2016). Previous reports show that proteolytic activity and milk-clotting specific activity of protease extracted from $M$. oleifera increase during seed germination (Wang et al., 2020). Moreover, in a recent study conducted by our group, a novel cysteine peptidase (MoCP) obtained from germinated $M$. oleifera seeds was characterized and exhibited good milk-clotting activity, high stability at acidic $\mathrm{pH}$, and 
good thermostability for consideration as a promising vegetable rennet (Wang et al., 2021). However, the specific milk-clotting properties of $\mathrm{MoCP}$ on bovine caseins have not yet been elucidated.

More than $95 \%$ of casein in bovine milk is found in the form of micelles with colloidal dispersion; $\kappa-\mathrm{CN}$ is located on the micelle surface, whereas $\alpha-\mathrm{CN}$ and $\beta-\mathrm{CN}$ are distributed in the interior due to their hydrophobic properties (McMahon and Oommen, 2008; Li and Zhao, 2019). During the initial phase of milk coagulation, rennet hydrolyzes $\kappa-\mathrm{CN}$ and destabilizes casein micelles, thus resulting in milk gelation (Yegin et al., 2011). Different milk-clotting proteases have differing specificity for $\kappa-\mathrm{CN}$ and other casein fractions (e.g., chymosin present in calf rennet specifically cleaves k-CN at the Phe105-Met106 peptide bond during milk coagulation and is thus the major enzyme cleavage site used in cheese making; Galán et al., 2008; Yegin et al., 2011). Interestingly, the cysteine protease from Dregea sinensis Hemsl. and the metalloproteinase from Paenibacillus spp. BD3526 have been shown to cleave $\kappa-\mathrm{CN}$ at peptide bonds Ser104-Phe105 and Met106-Ala107, respectively (Zhang et al., 2015; Hang et al., 2016). Majumder et al. (2015) demonstrated that an extracellular metalloprotease (ACPS) was preferentially active toward $\kappa-\mathrm{CN}$, whereas the hydrolysis of $\alpha-\mathrm{CN}$ and $\beta$-CN by the milk-clotting protease proceeded slowly. Therefore, the ability of milk-clotting proteases to hydrolyze $\alpha-\mathrm{CN}, \beta-\mathrm{CN}$, and $\kappa-\mathrm{CN}$ present in bovine milk is key for milk coagulation. Moreover, different milkclotting proteases have been shown to act on $\mathrm{k}-\mathrm{CN}$ and produce distinct cleavage sites, hence forming specific hydrolysis patterns, which are a result of differences in milk-clotting mechanism.

In the present study, the hydrolytic capacity on bovine $\alpha-\mathrm{CN}, \beta-\mathrm{CN}$, and $\kappa-\mathrm{CN}$ fractions by MoCP obtained from germinated $M$. oleifera seeds was determined. In addition, changes in the microscopic dynamics of flocculation reaction between $\mathrm{MoCP}$ and $\kappa-\mathrm{CN}$ further revealed the underlying milk-clotting mechanism. A better understanding of the specific milk-clotting properties of MoCP can enable site-directed mutagenesis to improve substrate binding. This may elucidate the interaction between residues near the cleavage point and enzyme subsites, thus leading to the development of a plant-derived rennet with potential application in cheese making.

\section{MATERIALS AND METHODS}

\section{Analytical Reagents}

Moringa oleifera (PKm2) plants were obtained in DeHong, Yunnan, China. The M. oleifera seeds were cultured as described previously (Wang et al., 2020). The cysteine peptidase MoCP was purified from the extract of germinated seeds (the crushed seeds were mixed with $0.3 \mathrm{M} \mathrm{NaCl}$ at a ratio of $1 \mathrm{~g}$ per $5 \mathrm{~mL}$, and agitated for $30 \mathrm{~min}$ at $30^{\circ} \mathrm{C}$ at $\mathrm{pH} 7.15$ ) using ammonium sulfate precipitation at 40 to $50 \%$ saturation and preparative HPLC separation with C18 silica gel column (SinoChrom ODS-BP; 250mm $\times 20 \mathrm{~mm}, 10$ $\mu \mathrm{m})$ in a gradient system of acetonitrile $(15-36 \%)$ and ultrapure water $(85-64 \%)$ for $20 \mathrm{~min}$ at a flow rate of $25 \mathrm{~mL} / \mathrm{min}$ at $35^{\circ} \mathrm{C}$ using a measurement wavelength of $280 \mathrm{~nm}$. Bovine casein, $\alpha-\mathrm{CN}$ (95\% purity), $\beta-\mathrm{CN}$ (98\% purity), and $\kappa-\mathrm{CN}$ (80\% purity) were purchased from Sigma-Aldrich. All other chemicals used were of analytical grade.

\section{Casein Hydrolysis by MoCP}

The level of casein hydrolysis was determined according to Huang et al. (2011) with some modifications. Solutions of $\alpha-\mathrm{CN}, \beta-\mathrm{CN}$, and $\kappa-\mathrm{CN}$ were prepared separately by dissolving $50 \mathrm{mg}$ of each substrate into $10 \mathrm{~mL}$ of $10 \mathrm{mmol} / \mathrm{L}$ phosphate buffer ( $\mathrm{pH} 6.5$ ). The $\mathrm{MoCP}$ at a concentration of $5 \mathrm{mg} / \mathrm{mL}$ was added to each substrate in a ratio of 1:10 (enzyme/substrate; $\mathrm{vol} / \mathrm{vol}$ ), and the mixture was submitted to hydrolysis at $60^{\circ} \mathrm{C}$ for $5,15,30,60,120$, and $180 \mathrm{~min}$. Hydrolysis was halted by heating the hydrolysates at $100^{\circ} \mathrm{C}$ for 15 min. Calf rennet $(5 \mathrm{mg} / \mathrm{mL})$, which was considered the control sample, was tested against 3 caseins at $40^{\circ} \mathrm{C}$ for $5 \mathrm{~min}$ and $3 \mathrm{~h}$. The degree of casein hydrolysis in all samples was determined by SDS-PAGE with $4 \%$ (wt/ vol) stacking gel and 15\% (wt/vol) resolving gel.

Under the same condition, MoCP at $5 \mathrm{mg} / \mathrm{mL}$ was reacted with equal concentrations of bovine casein, $\alpha-\mathrm{CN}, \beta-\mathrm{CN}$, and $\kappa-\mathrm{CN}$ at a 1:1 (enzyme/substrate; $\mathrm{vol} / \mathrm{vol}$ ) ratio at $60^{\circ} \mathrm{C}$ for $1 \mathrm{~h}$; the same concentration $\left(5 \mathrm{mg} / \mathrm{mL}\right.$ ) of calf rennet was tested for $1 \mathrm{~h}$ at $40^{\circ} \mathrm{C}$. The extent of casein hydrolysis was also determined by SDS-PAGE.

\section{Determination of the Molecular Weights of Products Derived from Casein Hydrolysis by MoCP}

Solutions of $\alpha-\mathrm{CN}, \beta-\mathrm{CN}$, and $\kappa-\mathrm{CN}$ at concentrations of $5 \mathrm{mg} / \mathrm{mL}$ were prepared separately in $10 \mathrm{mmol} / \mathrm{L}$ phosphate buffer ( $\mathrm{pH} 6.5$ ), and $\mathrm{MoCP}$ at $5 \mathrm{mg} / \mathrm{mL}$ was added to the substrate solutions in a ratio of $1: 10$ (enzyme/substrate; vol/vol) and placed at $60^{\circ} \mathrm{C}$ for $1 \mathrm{~h}$. Obtained hydrolysates were then filtered through a 10$\mathrm{kDa}$ UF membrane to yield low molecular weight hydrolysates. In addition, $\mathrm{\kappa}-\mathrm{CN}$ hydrolysates were obtained with a 12-h extended reaction for detecting potential sources of functional peptides. The molecular weights 
of resulting hydrolysates were analyzed in an AB Sciex MALDI-TOF/TOF 5800 system (Sciex, Framingham) using the linear method in a positive ion mode. Data acquisition was performed in the 4000 Series Explorer software v3.5.

\section{Analysis of the Cleavage Site on $\mathrm{K}-\mathrm{CN}$ Hydrolyzed by MoCP}

The cleavage site on $\kappa$-CN hydrolyzed by MoCP was determined as described by Luo et al. (2018) with some modifications. A solution of $\kappa-\mathrm{CN}$ at a concentration of $5 \mathrm{mg} / \mathrm{mL}$ was prepared in $10 \mathrm{mmol} / \mathrm{L}$ phosphate buffer (pH 6.5). The MoCP at $5 \mathrm{mg} / \mathrm{mL}$ was added to the $\kappa$-CN solution at a ratio of 1:10 (enzyme/substrate; $\mathrm{vol} / \mathrm{vol}$ ), and the mixture was incubated at $60^{\circ} \mathrm{C}$ for 1 $\mathrm{h}$ until complete milk clotting. The mixture was placed in a water bath at $100^{\circ} \mathrm{C}$ for $15 \mathrm{~min}$ and then submitted to separation by SDS-PAGE. The target band was excised from the gel and digested with trypsin overnight at $37^{\circ} \mathrm{C}$. The obtained trypsin digests were lyophilized and analyzed in a TripleTOF 5600 LC-MS/MS system (Sciex). Obtained data were searched against bovine entries available in the UniProt protein sequence database, using ProteinPilot v4.5 (Sciex).

\section{Analysis of the Cleavage Sites on $\alpha-C N$ and $\beta-C N$ Hydrolyzed by MoCP}

The cleavage sites on $\alpha-\mathrm{CN}$ and $\beta$-CN hydrolyzed by $\mathrm{MoCP}$ were determined as described by Zhang et al. (2015) with some modifications. The MoCP reacted separately on $\alpha-\mathrm{CN}$ and $\beta$-CN at a ratio of 1:10 (enzyme/substrate; vol/vol) at $60^{\circ} \mathrm{C}$ for $1 \mathrm{~h}$. Resulting clots were desalinated at $4^{\circ} \mathrm{C}$ in Amicon $3 \mathrm{~K}$ UF centrifuge tubes (Millipore) to yield casein hydrolysates. The SDS-PAGE was then performed to separate hydrolyzed products, and target bands on polyvinylidene fluoride films were excised after transmembrane electrophoresis. The AA sequence at the $\mathrm{N}$ terminus of resulting peptides was determined using a PPSQ-31A protein polypeptide sequence detector (Shimadzu Co.), and cleavage sites on $\alpha-\mathrm{CN}$ and $\beta-\mathrm{CN}$ were analyzed using the PPSQ-30 data processing software (Shimadzu Co.).

\section{Microcosmic Observation of the Flocculation Reaction Between MoCP and $\mathrm{K}-\mathrm{CN}$}

The MoCP solution $(5 \mathrm{mg} / \mathrm{mL})$ was mixed with a $\kappa$-CN solution $(5 \mathrm{mg} / \mathrm{mL}$ ) at a ratio of $1: 1$ (enzyme/ substrate; vol/vol) and placed at $60^{\circ} \mathrm{C}$ for $3 \mathrm{~h}$. The mixture was screened, and images were obtained after $0,10,30,60,90,120,150$, and $180 \mathrm{~min}$ from the start of reaction in a Smartzoom 5 3-dimensional microscope
(Zeiss) using the following parameters: magnification of $1,000 \times$; mixture placed directly onto a microscope slide; automatic focus; variable exposure time; coaxial illumination; and depth-of-focus lenses extension). Changes in the size and quantity of flocs of MoCP and $\kappa-\mathrm{CN}$ were determined using the images captured during the reaction.

\section{Statistical Analysis}

All experiments were performed in triplicate. Date are presented as a mean value \pm standard deviation.

\section{RESULTS AND DISCUSSION}

\section{Hydrolysis of Caseins by MoCP}

The effects of $\mathrm{MoCP}$ on $\alpha-\mathrm{CN}, \beta-\mathrm{CN}$, and $\kappa-\mathrm{CN}$ fractions as evidenced after SDS-PAGE are presented in Figure 1A, B, C, and D. The MoCP acted on $\alpha-\mathrm{CN}, \beta-\mathrm{CN}$, and $\kappa-\mathrm{CN}$, producing varying degrees of hydrolysis. With an enzyme-to-substrate ratio of 1:10 (enzyme/substrate; vol/vol), hydrolysis products appeared in all 3 reaction mixtures after $5 \mathrm{~min}$, and the band corresponding to the hydrolysis product of $\kappa-\mathrm{CN}$ was more evident. This indicated that MoCP might hydrolyze $\kappa-\mathrm{CN}$ first and lead to an effective accumulation of hydrolysates, an evidence that is in line with the cleavage pattern of an ACPS isolated from Termitomyces clypeatus MTCC 5091 and a cysteine protease from the latex of Ficus johannis (Majumder et al., 2015; Afsharnezhad et al., 2019). In the control group (Supplemental Figure S1A-C, https://doi.org/ $10.17632 / \mathrm{m} 2 \mathrm{wt} 9 \mathrm{gc} 2 \mathrm{~ms} .1$ ), calf rennet also hydrolyzed the 3 caseins to various degrees as follows: $\alpha-\mathrm{CN}$ hydrolysis did not appear within the initial 5 min; $\beta$-CN and $\kappa$-CN showed a certain degree of hydrolysis; and a product showing a similar molecular weight to $\kappa-\mathrm{CN}$ was formed, indicating that calf rennet hydrolyzed $\kappa-\mathrm{CN}$ first and produced hydrolysates. These findings are consistent with the hydrolysis specificity of calf rennet as previously reported by Uniacke-Lowe et al. (2013) and Jensen et al. (2015). Furthermore, the band identified as $\alpha-C N$ remained intact throughout the reaction (Figure $1 \mathrm{~A}$ ), suggesting that $\alpha-\mathrm{CN}$ might be more resistant to the action of MoCP. Bovine $\alpha-\mathrm{CN}$ is composed of $\alpha_{\mathrm{S}^{1}}-\mathrm{CN}$ and $\alpha_{\mathrm{S}_{2}}-\mathrm{CN}$; the latter is the most resistant (Grappin et al., 1985), whereas the Phe23Phe24 peptide bond in $\alpha_{S 1}-\mathrm{CN}$ is the most sensitive to the action of milk-clotting proteases (Macedo et al., 1993). This partly explains $\alpha-\mathrm{CN}$ being more resistant to hydrolysis by MoCP. Conversely, bands identified as $\beta-\mathrm{CN}$ and $\kappa$-CN were of low intensity after $30 \mathrm{~min}$ of reaction time. Bands of $\beta$-CN hardly changed during 
the reaction, whereas the band of $\kappa$ - $\mathrm{CN}$ became narrower from $30 \mathrm{~min}$ to $3 \mathrm{~h}$ of reaction time. Thus, the degree of activity of MoCP was greater on $\kappa-\mathrm{CN}$ and less pronounced on $\beta-\mathrm{CN}$ and $\alpha-\mathrm{CN}$. Milk-clotting protease has a strong ability to hydrolyze $\kappa-\mathrm{CN}$ and a relatively weak ability to hydrolyze $\alpha-\mathrm{CN}$ and $\beta-\mathrm{CN}$, which is conducive to cheese manufacture (An et al., 2014; Kethireddipalli and Hill, 2015). It is also known that hydrolysis of $\alpha-\mathrm{CN}$ and $\beta-\mathrm{CN}$ positively affects sensory and mechanical properties of cheese, such as hardness, texture, and flavor development during ripening. Additionally, weak hydrolysis of $\alpha-\mathrm{CN}$ and $\beta-\mathrm{CN}$ avoids the release of bitter peptides during cheesemaking (An et al., 2014), thus indicating a desirable property of MoCP. In contrast, $\alpha-\mathrm{CN}$ and $\beta-\mathrm{CN}$ were completely hydrolyzed by calf rennet in $3 \mathrm{~h}$, as a product of $\alpha-\mathrm{CN}$ hydrolysis was observed, and reaction of $\beta$-CN did not yield any hydrolysates, which might have been further hydrolyzed into smaller, undetectable peptides. However, products of calf rennet-hydrolyzed $\mathrm{k}$-CN did not change substantially after $3 \mathrm{~h}$ of reaction compared with a 5-min reaction, implying that MoCP hydrolyzed $\kappa-\mathrm{CN}$ to a greater extent compared with calf rennet, although the ability to hydrolyze $\alpha-\mathrm{CN}$ and $\beta-\mathrm{CN}$ was weaker than that of calf rennet.

In contrast, a sufficient amount of MoCP has been shown to effectively hydrolyze CN, $\alpha-\mathrm{CN}, \beta-\mathrm{CN}$, and $\kappa$-CN within $1 \mathrm{~h}$ with a ratio of 1:1 (enzyme:substrate; vol/vol; Figure 1D) in which $\kappa$-CN would be completely hydrolyzed, further confirming the greatest activity of $\mathrm{MoCP}$ on $\mathrm{k}$-CN. In the control group (Supplemental Figure S1D, https://doi.org/10.17632/m2wt9gc2ms.1), calf rennet hydrolyzed those substrates only partially. Collectively, MoCP at sufficient amounts was able to hydrolyze all 3 caseins at a greater extent compared with calf rennet, and lower amounts of MoCP were necessary to lead to milk coagulation.

In addition, with prolonged reaction time, all 3 casein fractions were hydrolyzed to form relatively stable hydrolysates as follows: $\alpha_{\mathrm{S1}}$-CN yielded a peptide band with a molecular weight greater than $15 \mathrm{kDa} ; \beta-\mathrm{CN}$ formed 2 peptide bands with molecular weights greater than $15 \mathrm{kDa}$ and $25 \mathrm{kDa}$; and $\mathrm{\kappa}$-CN yielded a $15 \mathrm{kDa}$ peptide band (Figure 1A, B, C). Hydrolysis of $\kappa$-CN by $\mathrm{MoCP}$ led to the formation of a $15-\mathrm{kDa}$ peptide from as early as $5 \mathrm{~min}$ into the reaction, indicating the specificity of the peptidase for $\mathrm{k}$-CN hydrolysis. It is well known that rennet can specifically hydrolyze $\kappa-\mathrm{CN}$ into partial $\kappa-\mathrm{CN}$ and caseinomacropeptide, further acting on $\alpha-\mathrm{CN}$ and $\beta-\mathrm{CN}$ and leading to milk coagulation (Dwyer et al., 2005). The digestion pattern of $\kappa-\mathrm{CN}$ resultant from activity of MoCP was very similar to that by other plant-derived proteases. For example, the aspartic protease from Cirsium vulgare and tamarillo fruit protease both generated a $15-\mathrm{kDa}$ peptide $(\mathrm{Lu}-$ frano et al., 2012; Li et al., 2018). Additionally, the protease obtained from Solanum dubium seeds produced a peptide band of approximately $16 \mathrm{kDa}$ (Mohamed Ahmed et al., 2010). Collectively, к-CN hydrolysates have relative stability, which provide an important basis for the determination of the cleavage site on $\kappa$-CN by $\mathrm{MoCP}$.

\section{Potential Source of Functional Peptides in Casein Hydrolysates}

The degree of hydrolysis of caseins can affect milkclotting time and mechanics. It can also yield functional peptides with different molecular weights and specific AA sequences, thus making the resulting cheese a potential functional food (Lee and Warthesen, 2006). As shown in Figure 2A, B, C, the 3 evaluated caseins were mainly hydrolyzed into macromolecular peptides after 1 $\mathrm{h}$ of hydrolysis by MoCP. However, hydrolysis products with molecular weight lower than $10 \mathrm{kDa}$ were also produced. Of these, peptides with molecular weight of 5 to $7.5 \mathrm{kDa}$ were generated from $\alpha$-CN hydrolysis, whereas peptides of 5 to $5.5 \mathrm{kDa}$ and 5 to $6 \mathrm{kDa}$ were produced from the hydrolysis of $\beta-\mathrm{CN}$ and $\kappa-\mathrm{CN}$, respectively, which might have been produced as the result of secondary hydrolysis of caseins. A large number of low molecular weight peptides, most of which were 2 to 4 $\mathrm{kDa}$, were produced after $12 \mathrm{~h}$ of reaction with MoCP as a result of $\kappa$-CN hydrolysis (Figure 2D). The above peptides generated from casein hydrolysis had different molecular weight distributions and possibly possessed specific AA sequences, which require further identification. It has been demonstrated that peptides generated from the hydrolysis of caseins by the milk-clotting protease BL312 have various functional properties such as antioxidant, antimicrobial, antihypertensive, and immunomodulating activities, as well as the ability to inhibitor of angiotensin-converting enzyme (Zhang et al., 2019). Bioactive peptides with antioxidant, antimicrobial, and angiotensin-converting enzyme inhibitory activity have also been found in Cheddar, Coalho, Mozzarella, and other cheeses (Santiago-López et al., 2018). Therefore, the use of MoCP in the manufacture of cheese or other dairy products will likely enrich the final product with a variety of functional peptides to be considered a potential functional food. However, another important challenge for producing high-quality cheese in terms of flavor and texture involves reducing bitterness derived from proteolysis, which is linked to the release of peptides containing aromatic AA (da Silva, 2018). For instance, the abundance of low mo- 

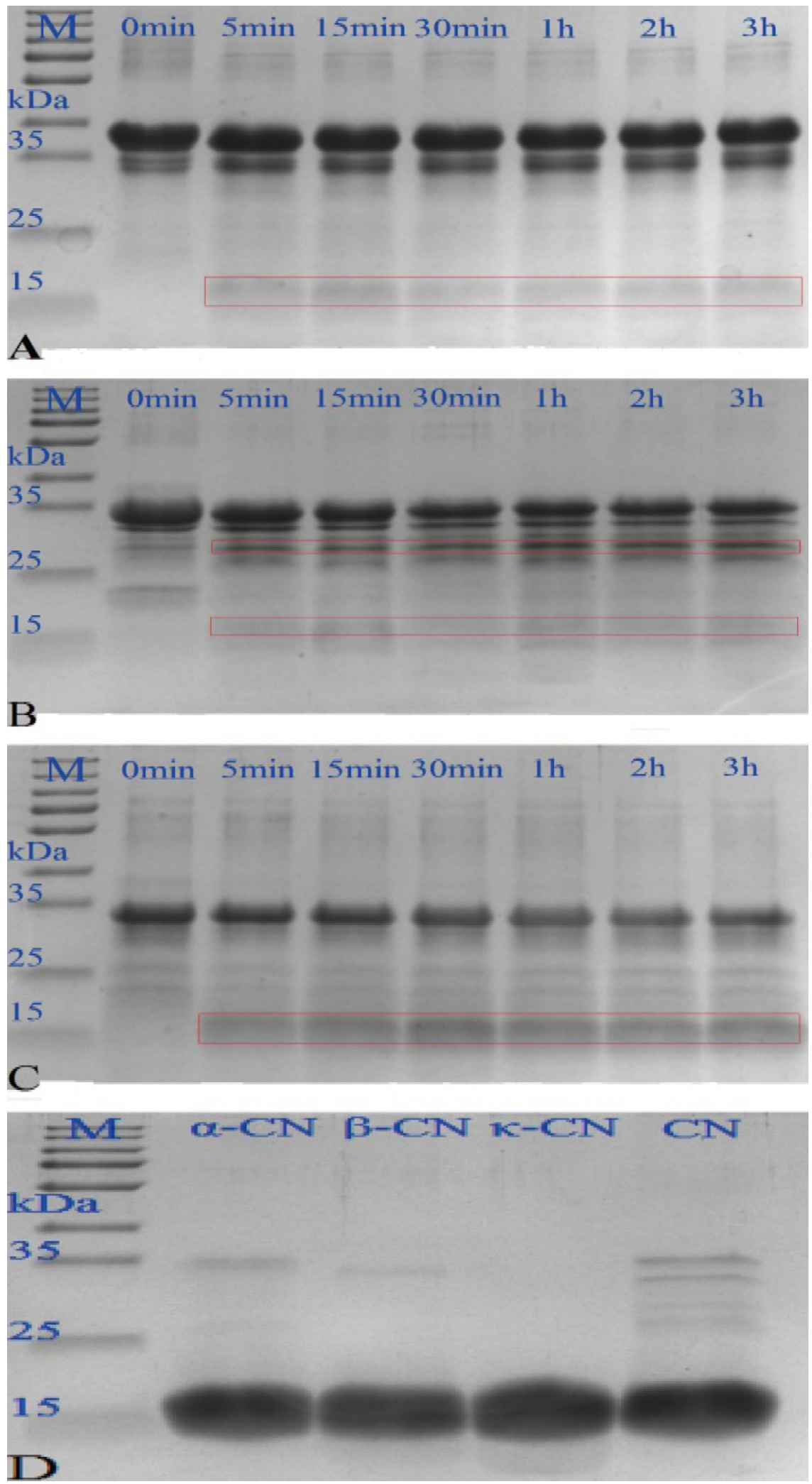

Figure 1. The SDS-PAGE patterns of $\alpha-\mathrm{CN}(\mathrm{A}), \beta-\mathrm{CN}(\mathrm{B})$, and $\kappa-\mathrm{CN}(\mathrm{C})$ hydrolyzed with the cysteine peptidase from germinated Moringa oleifera seeds at different reaction times $(0,5,15,30,60,120$, and $180 \mathrm{~min}$ ) with enzyme to substrate ratio of 1:10 (vol/vol); (D) SDS-PAGE patterns of whole $\mathrm{CN}, \alpha-\mathrm{CN}, \beta-\mathrm{CN}$, and $\kappa-\mathrm{CN}$ hydrolyzed with the cysteine peptidase for $1 \mathrm{~h}$ with enzyme to substrate ratio of $1: 1$ (vol/vol). Lane M: protein marker. 

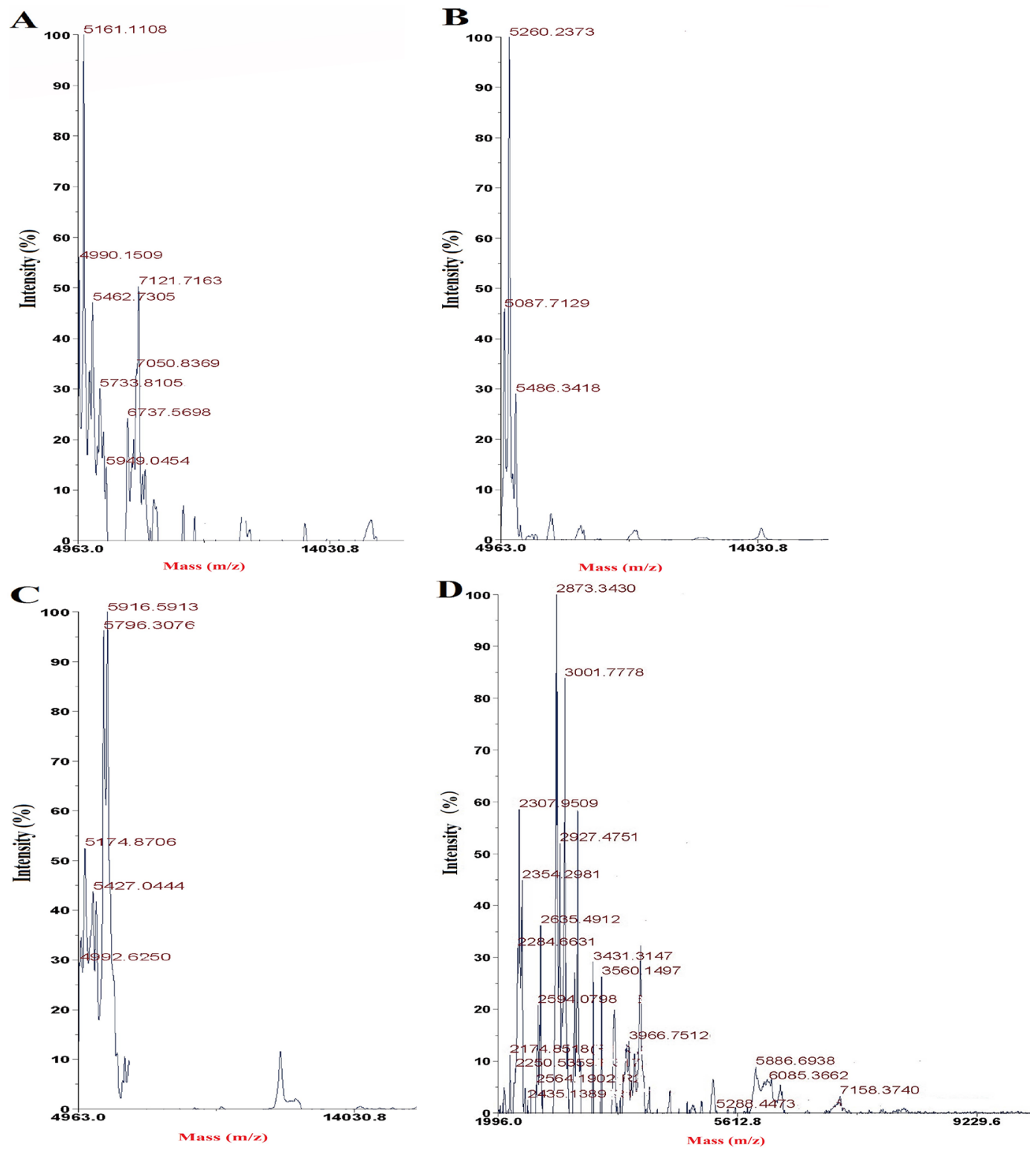

Figure 2. Molecular weights of peptides in the reaction mixtures resulting from the hydrolysis of $\alpha-\mathrm{CN}(\mathrm{A}), \beta-\mathrm{CN}(\mathrm{B})$, and $\kappa-\mathrm{CN}(\mathrm{C})$ for $1 \mathrm{~h}$ as well as prolonged hydrolysis of $\kappa-\mathrm{CN}$ (D) for $12 \mathrm{~h}$ by the cysteine peptidase from germinated Moringa oleifera seeds as determined by MALDI-TOF/TOF.

lecular weight hydrophobic peptides, such as $\alpha_{\mathrm{S1}^{-}} \mathrm{CN}$ 2009). Milk-clotting proteases may also lead to the (f1-9) and $\beta$-CN (f193-209), is associated with the appearance of bitterness in cheese (Fernández-Salguero, development of bitterness in cheese after storage and poor yield (Vishwanatha et al., 2010).

Table 1. Identification by LC-MS/MS of peptide sequences of in-gel tryptic digests of peptide fractions derived from hydrolysis of $\kappa$-CN by the novel cysteine peptidase from germinated Moringa oleifera seeds

\begin{tabular}{|c|c|c|c|c|c|c|}
\hline Peptide sequence & $\begin{array}{l}\text { Mass to charge } \\
\text { ratio }(m / z)\end{array}$ & $\begin{array}{c}\text { Coverage } \\
(\%)\end{array}$ & $\begin{array}{c}\text { Reliability } \\
(\%)\end{array}$ & \multicolumn{2}{|c|}{ Molecular weight (Da) } & Peptide origin \\
\hline SPAQILQWQVLSNTVPAK & 991.04 & 35.26 & 99.00 & $1,980.07 \pm 0.56$ & $1,980.06$ & к-CN (90-107) \\
\hline HPHPHLSFMAI & 542.29 & 35.26 & 98.39 & $1,286.51 \pm 0.55$ & $1,286.52$ & к-CN (119-129) \\
\hline
\end{tabular}



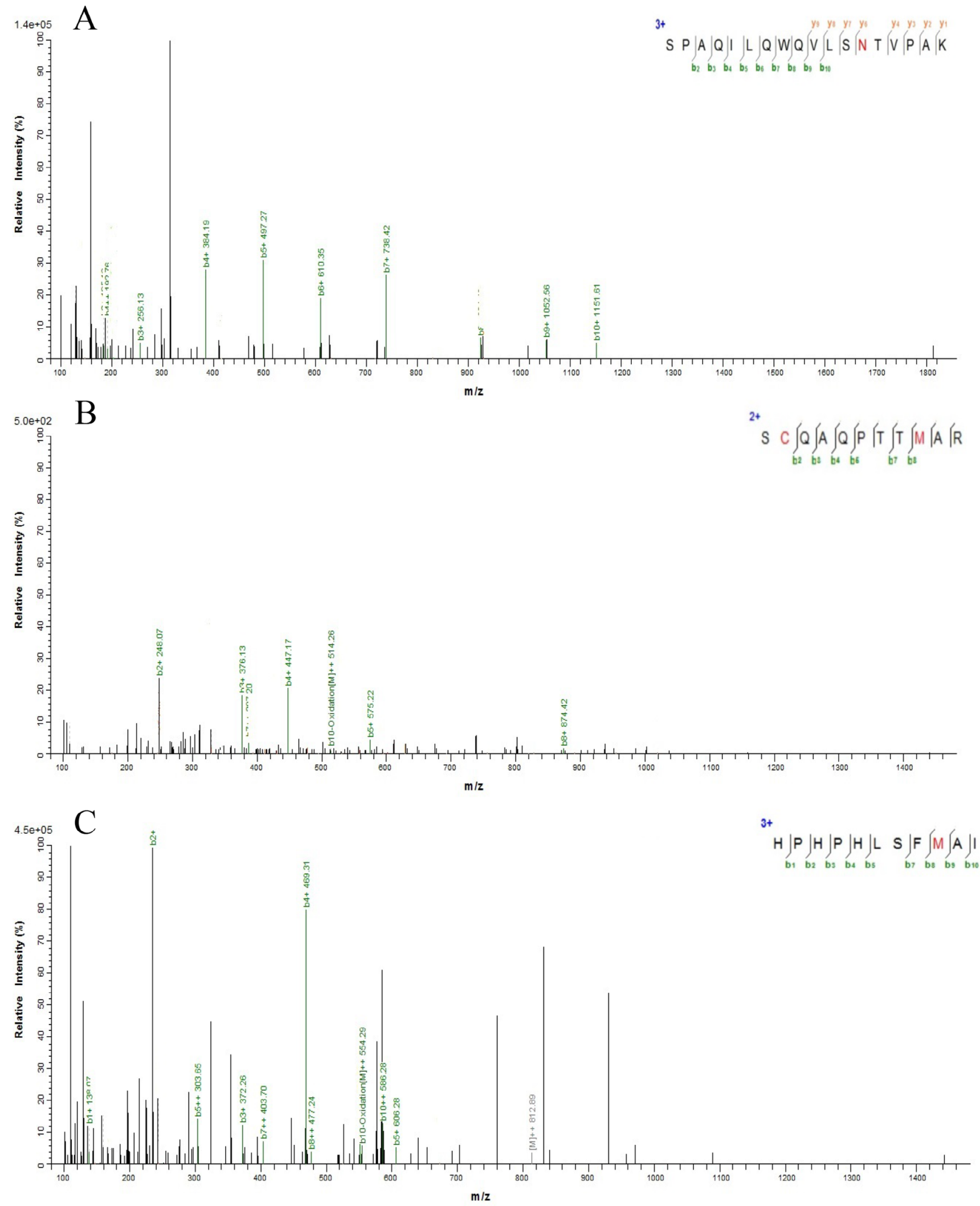

Figure 3. Tandem MS identification of 3 peptide sequences of in-gel tryptic digests of peptide fractions derived from hydrolysis of -CN by the novel cysteine peptidase from germinated Moringa oleifera seeds. (A-C): Mass chromatogram of SPAQILQWQVLSNTVPAK, SCQAQPTTMAR, and HPHPHLSFMAI, respectively. 
Table 2. Specific cleavage sites of plant-derived milk-clotting proteases on bovine $\kappa$-CN

\begin{tabular}{llll}
\hline Enzyme type & Plant source & Preferential cleavage site & Reference \\
\hline Cysteine peptidase & Germinated Moringa oleifera seeds & Ile129-Pro130 & Current study \\
Cysteine protease & Cynanchum otophyllum Schneid. & Ser132-Thr133 & Luo et al., 2018 \\
Calf rennet & Cuckling calve & Phe105-Met106 & Sousa and Malcata, 1998 \\
Microbial chymosin & Glutinous rice wine & Thr94-Met95 & Jiang et al., 2007 \\
Metalloproteinase & Paenibacillus spp. BD3526 & Met106-Ala107 & Hang et al., 2016 \\
\hline
\end{tabular}

\section{Cleavage Sites on Caseins by MoCP}

In general, specific hydrolysis of $\kappa$-CN results in milk coagulation (Galán et al., 2008). To further identify the cleavage site of $\mathrm{MoCP}$ on $\mathrm{k}-\mathrm{CN}$, in-gel tryptic digestion followed by LC-MS/MS peptide identification was conducted on reaction mixtures. Three major peptide sequences were detected (Table 1) with $95 \%$ reliability and coverage rates over $30 \%$, thus enabling the identification of the C-terminus of $\kappa$-CN. The glycomacropeptide was produced mainly by the hydrolysis of the $\mathrm{N}$ terminus of $\kappa-\mathrm{CN}$, which failed to interact with

A
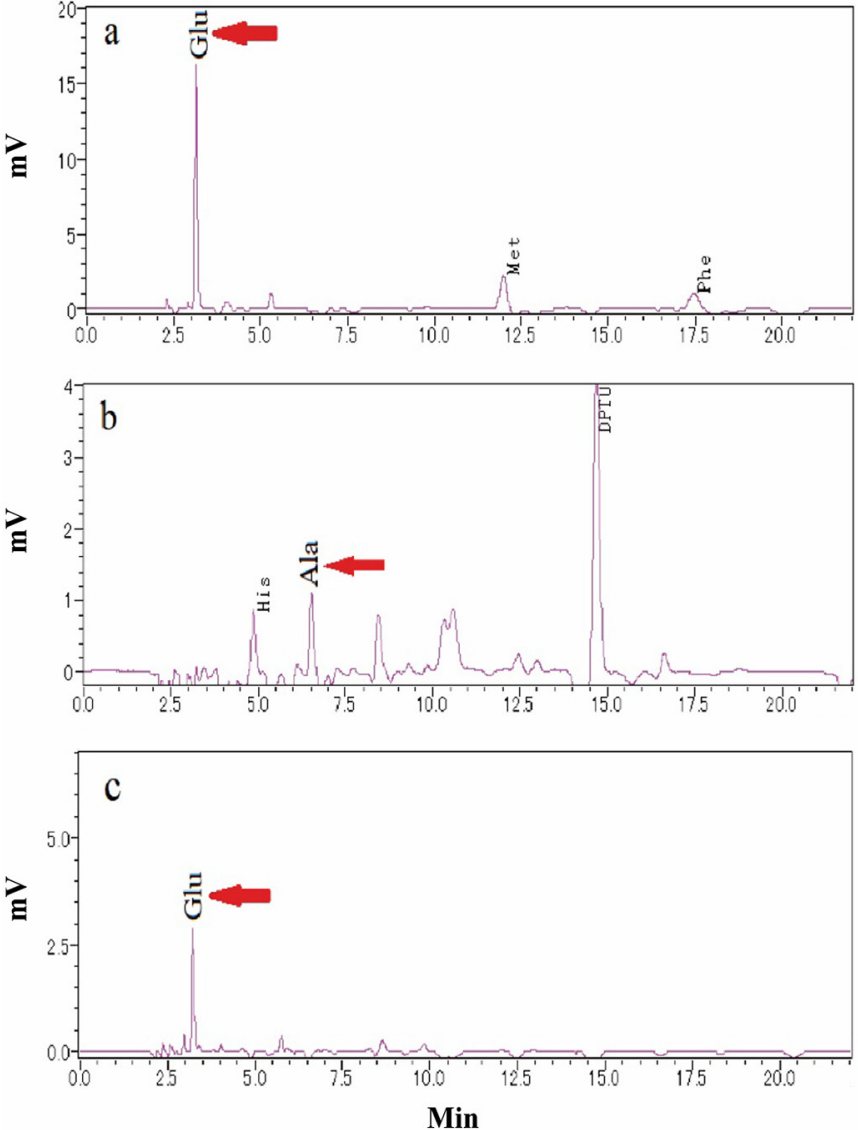

the gel matrix and to be detected by SDS-PAGE due to its high acidic and polyhydroxy nature (Coolbear et al., 1996). Importantly, because $\alpha_{\mathrm{S}^{-}} \mathrm{CN}$ and $\alpha_{\mathrm{S}_{2}} \mathrm{CN}$ appear as constituents of $\kappa$-CN, these compounds can interfere with the detection signal in SDS-PAGE and MS identification of $\kappa$-CN target products.

It is well known that trypsin-hydrolyzed proteins or peptides are preferentially cleaved at AA residues Arg and Lys (Keil, 2012). Therefore, by eliminating peptide segments resulting from trypsin digestion and overlapping peptides, and based on in-gel digestion results (Figure $3 \mathrm{~A}, \mathrm{~B}, \mathrm{C}$ ), the cleavage site on $\kappa-\mathrm{CN}$
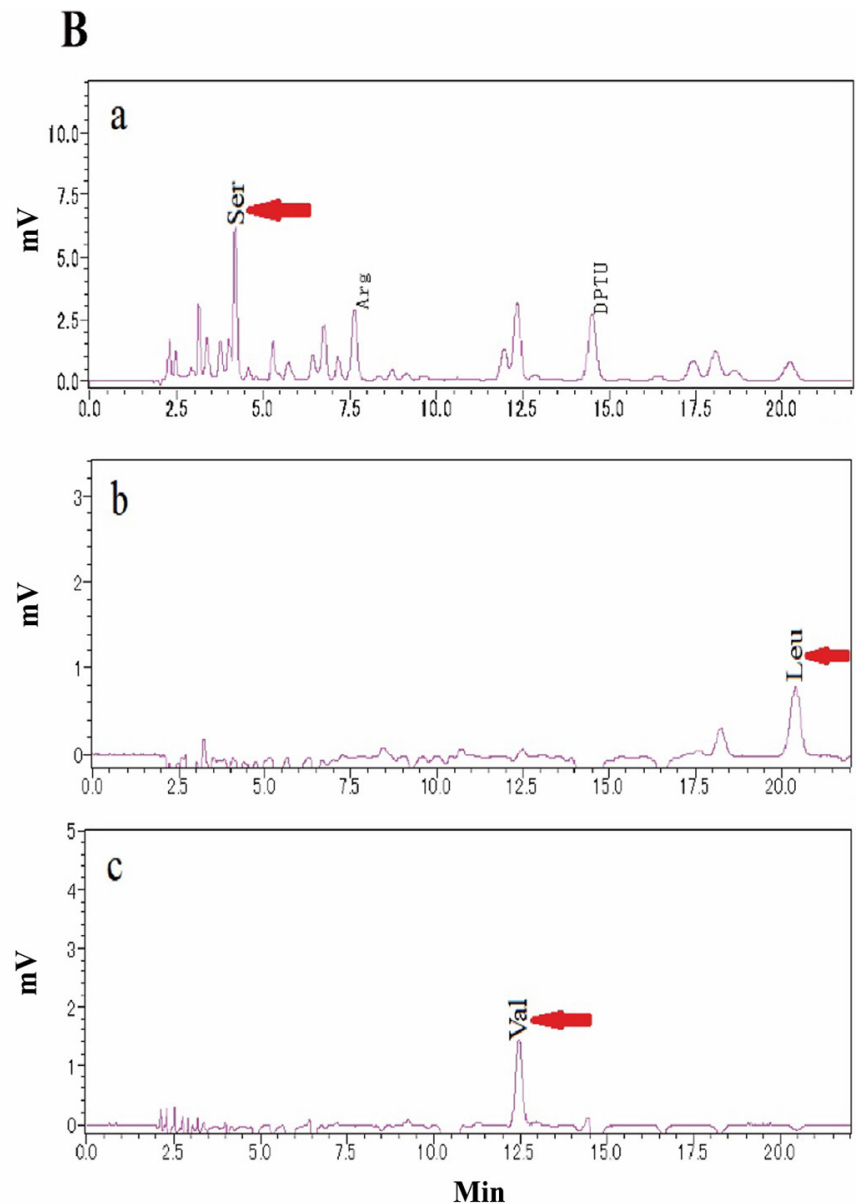

Figure 4. N-terminal sequencing of peptides in $\alpha-\mathrm{CN}(\mathrm{A})$ and $\beta-\mathrm{CN}$ (B) hydrolysates. (A) a-c: AA sequences with Glu-(E), Ala-(A), and Glu-(E) residues; (B) a-c: AA sequences with Ser-(S), Leu-(L), and Val-(V) residues. DPTU: $N, N^{\prime}$-diphenylthiourea. 
by MoCP was at residue Ile129-Pro130. Moreover, $\kappa-\mathrm{CN}$ was hydrolyzed into the main peptide (129 AA) of $\kappa$-CN (f1-129) with a molecular weight of 14,895.37 Da, which agreed with SDS-PAGE results $(\sim 15 \mathrm{kDa}$, Figure 1C). Rennet substitutes have been studied at length, but only few studies have explored the specific activity of milk-clotting proteases on $\mathrm{k}-\mathrm{CN}$ ( $\mathrm{Li}$ et al., 2018). As shown in Table 2, the reported cleavage site of MoCP on $\kappa-C N$ (Ile129-Pro130) is similar to that of the cysteine protease isolated from Cynanchum otophyllum Schneid. (Ser132-Thr133; Luo et al., 2018), but significantly different from that of calf rennet (Phe105Met106), microbial chymosin from glutinous rice wine (Thr94-Met95), and a novel milk-clotting metalloproteinase obtained from Paenibacillus spp. BD3526 (Met106-Ala107; Sousa and Malcata, 1998; Jiang et al., 2007; Hang et al., 2016). Collectively, results indicate that proteases from different sources produce different cleavage sites on $\kappa$-CN, which ultimately leads to different milk-clotting time and specificity.

In addition, $\mathrm{N}$-terminal sequencing was performed on 2 hydrolysis products of $\alpha-\mathrm{CN}$ and $\beta-\mathrm{CN}$, which both had molecular weight greater than $15 \mathrm{kDa}$. We took into consideration that the purity of $\alpha-\mathrm{CN}(95 \%)$ and $\beta-\mathrm{CN}(98 \%)$ used in this study was significantly higher than that of $\kappa-\mathrm{CN}(80 \%)$. As shown in Figure 4A, the $\mathrm{N}$-terminal AA sequence of the hydrolysis product of $\alpha_{\mathrm{S1}^{-}} \mathrm{CN}$ was Glu-Ala-Glu. The cleavage site by $\mathrm{MoCP}$ on $\alpha_{S_{1}}$ CN was Met75-Glu76 based on peptide sequence alignment, which generated the main hydrolysate of $\alpha_{\mathrm{S}_{1}}$-CN (f76-214) with a molecular weight of $16,072.01$ Da. The N-terminal AA sequence of the $\beta$-CN hydrolysate was Ser-Leu-Val (Figure 4B), which indicated that the cleavage site by MoCP on $\beta-\mathrm{CN}$ was Gln71-Ser72. A $\beta$-CN hydrolysate (f72-224) with a molecular weight of $17,057.19$ Da was formed, which was similar to a $17-\mathrm{kDa}$ hydrolysis product of $\beta$-CN generated from 1 $\mathrm{h}$ hydrolysis with tamarillo protease (Li et al., 2018). Overall, the above results agreed with the molecular weight of bands observed in SDS-PAGE (Figure 1A, $\mathrm{B})$. Collectively, the cleavage site on $\mathrm{\kappa}-\mathrm{CN}$ as well as on $\alpha-\mathrm{CN}$ and $\beta-\mathrm{CN}$ further revealed the specific milkclotting properties of MoCP obtained from germinated $M$. oleifera seeds, which have not yet been reported for other plant-derived rennet.

\section{Changes in Microcosmic Dynamic of the Flocculation Reaction of MoCP and $\mathrm{K}-\mathrm{CN}$}

Changes in casein micelles are intrinsic to the process of milk coagulation, and flocculation and hydrolysis of $\kappa$-CN by milk-clotting proteases is key for determining changes in casein micelles (de Kruif, 1992; Sandra et al., 2011). Currently, there is little evidence discussing changes in the microcosmic dynamic of the flocculation reaction between milk-clotting proteases and $\kappa$-CN that could help determine the effective flocculation time. Three-dimensional microscopy with super-depth of field has been increasingly used in several industrial sectors, including electronics, mechanical, materials, medical, chemistry and life sciences (Lazcano-Ramírez et al., 2018). In the food industry, this technique is mainly used to reveal the 3 -dimensional microstructure of the surface of food-packaging materials, rarely being used for dynamic microscopic observation of food or reaction processes (Miettinen et al., 2014). In the present study, flocculation between MoCP and $\mathrm{\kappa}-\mathrm{CN}$ was documented in a 3-dimensional microscope to further reveal the underlying milk-clotting mechanism. As shown in Figure 5, flocs in the reaction mixture were larger within the first $30 \mathrm{~min}$ of reaction, and the number of particles increased as the reaction progressed, thus the number and size of flocculated particles produced by MoCP increased throughout the reaction. Flocculated particles became smaller in size and number between 30 and 90 min of the start of the reaction, and further decreased between 90 and $180 \mathrm{~min}$, indicating that MoCP produced a secondary enzymatic hydrolysis of $\kappa$-CN partial hydrolysis products after 30 min of reaction, and the degree of hydrolysis progressively increased, which resulted in gradual hydrolysis of flocculated particles into more soluble low molecular weight peptides. This evidence also confirmed that the most effective flocculation reaction between MoCP and к-CN occurred within $30 \mathrm{~min}$, and the second enzymolysis occurred after that elapsed time. This second enzymolysis occurred earlier than that produced by Cynanchum otophyllum Schneid. protease QA on $\kappa$-CN hydrolysis products (120 min; Luo et al., 2018), but later than that by ACPS from Termitomyces clypeatus MTCC 5091 (5 min; Majumder et al., 2015). The rate of hydrolysis of caseins is considered one of the most important parameters in cheesemaking, affecting yield, flavor, and texture of cheese, and a firm curd is often produced as a result of slow hydrolysis of $\alpha-\mathrm{CN}$ and $\beta-\mathrm{CN}$ fractions (Pontual et al., 2012; Afsharnezhad et al., 2019). Therefore, the flocculation reaction between $\kappa-\mathrm{CN}$ and MoCP occurring within $30 \mathrm{~min}$ is crucial for adequate milk coagulation. By producing more flocs and destroying stable casein micelles within a short time, curd yield increases. Collectively, this study has revealed important insights into the specific milkclotting properties of MoCP. However, further research is needed to understand its coagulation mechanism through the evaluation of microstructural changes of casein micelles in the complex milk system. 


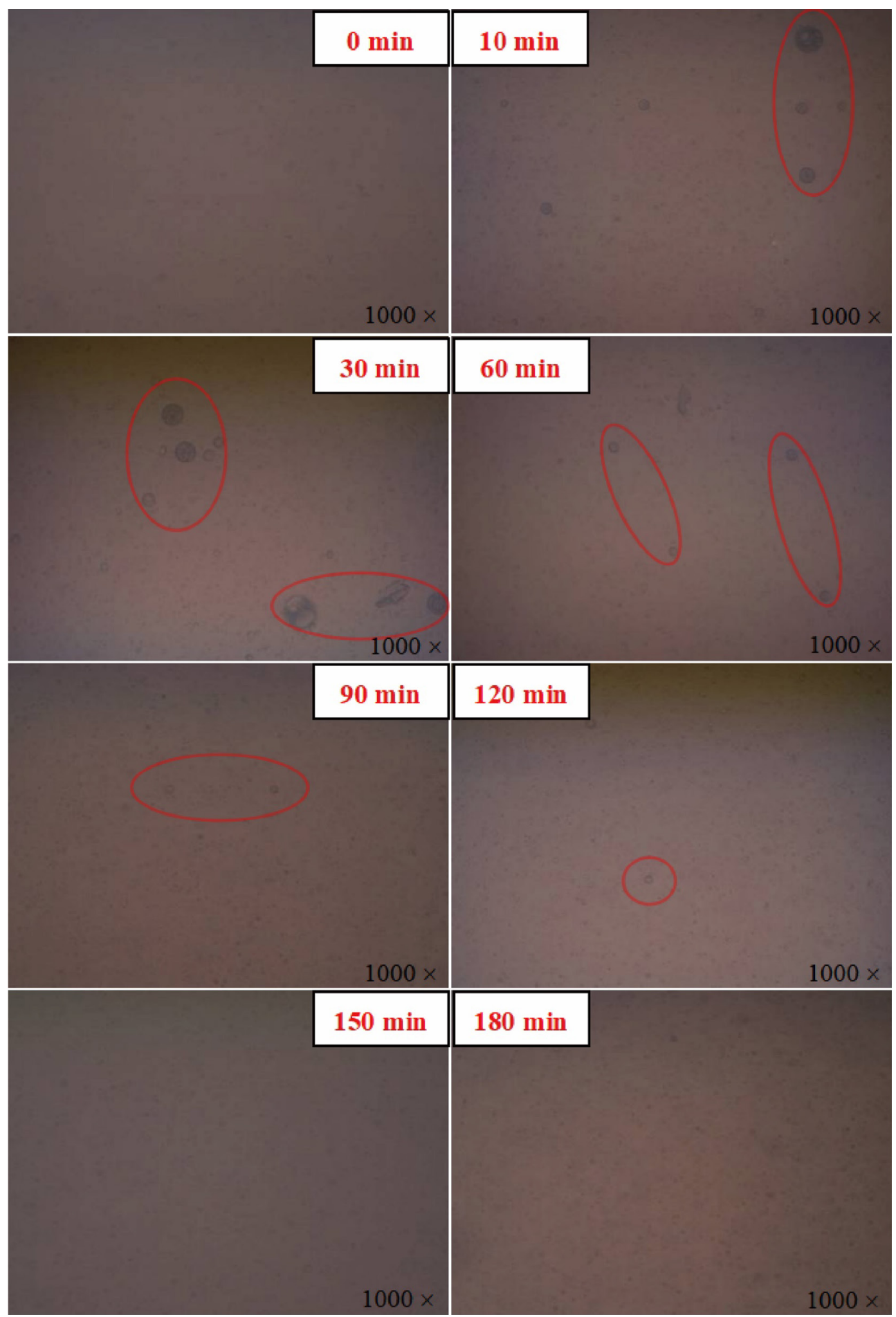

Figure 5. Observation of the flocculation reaction between the novel cysteine peptidase from germinated Moringa oleifera seeds and $\kappa$-CN at different reaction times in a 3-dimensional microscope with super-depth of field. 


\section{CONCLUSIONS}

The MoCP was shown to hydrolyze bovine $\alpha-\mathrm{CN}$, $\beta-\mathrm{CN}$, and $\kappa-\mathrm{CN}$ fractions. It exhibited optimal hydrolytic activity on $\kappa-\mathrm{CN}$, which was superior to calf rennet, but its ability to hydrolyze $\alpha-\mathrm{CN}$ and $\beta-\mathrm{CN}$ was weaker compared with that of calf rennet. Among identified cleavage sites on the 3 caseins, specific hydrolysis of $\kappa$-CN was confirmed at residue Ile129-Pro130 and generated a major peptide of 14,895.37 Da. The flocculation reaction of $\mathrm{MoCP}$ and $\kappa-\mathrm{CN}$ within 30 min was key to guaranteeing milk coagulation, and it may affect final curd yield. The present findings demonstrated the initial milk-clotting properties of $\mathrm{MoCP}$ from germinated M. oleifera seeds. However, further research is needed to elucidate the milk-clotting mechanism of $\mathrm{MoCP}$, including evaluating the activity of MoCP on synthetic substrates to determine whether hydrolysis occurs at sites identified and proposed in the present study. Finally, it would be of interest to measure the release of aromatic residues from casein hydrolysates hydrolyzed by MoCP to gauge the potential application of this enzyme in cheese manufacture.

\section{ACKNOWLEDGMENTS}

This work was supported by the National Natural Science Foundation of China (Beijing; grant nos. 31560431 and 31960462), the Applied Basic Research Foundation of Yunnan Province (Kunming, China; grant no. 2019FB052), and the Joint Agricultural Project of Yunnan Province (Kunming, China; grant no. 2018FG001-040). The authors have not stated any conflicts of interest.

\section{REFERENCES}

Afsharnezhad, M., S. S. Shahangian, and R. Sariri. 2019. A novel milkclotting cysteine protease from Ficus johannis: Purification and characterization. Int. J. Biol. Macromol. 121:173-182. https://doi .org/10.1016/j.ijbiomac.2018.10.006.

Alihanoğlu, S., D. Ektiren, Ç. Akbulut Çakır, H. Vardin, A. Karaaslan, and M. Karaaslan. 2018. Effect of Oryctolagus cuniculus (rabbit) rennet on the texture, rheology, and sensory properties of white cheese. Food Sci. Nutr. 6:1100-1108. https://doi.org/10 $.1002 /$ fsn3.649.

An, Z., X. L. He, W. D. Gao, W. Zhao, and W. B. Zhang. 2014. Characteristics of miniature cheddar-type cheese made by microbial rennet from Bacillus amyloliquefaciens: A comparison with commercial calf rennet. J. Food Sci. 79:M214-M221. https://doi.org/ 10.1111/1750-3841.12340.

Coolbear, K. P., D. F. Elgar, T. Coolbear, and J. S. Ayers. 1996. Comparative study of methods for the isolation and purification of bovine $\kappa$-casein and its hydrolysis by chymosin. J. Dairy Res. 63:61-71. https://doi.org/10.1017/S002202990003154X.

da Silva, R. R. 2018. Exploring microbial peptidases for cheese production: A viewpoint on the current conjecture. J. Agric. Food Chem. 66:1305-1306. https://doi.org/10.1021/acs.jafc.8b00018. de Kruif, C. G. 1992. Casein micelles: Diffusivity as a function of renneting time. Langmuir 8:2932-2937. https://doi.org/10.1021/ la00048a014.

Dong, K., S. Zhen, Z. Cheng, H. Cao, P. Ge, and Y. Yan. 2015. Proteomic analysis reveals key proteins and phosphoproteins upon seed germination of wheat (Triticum aestivum L.). Front. Plant Sci. 6:1017. https://doi.org/10.3389/fpls.2015.01017.

Dwyer, C., L. Donnelly, and V. Buckin. 2005. Ultrasonic analysis of rennet-induced pre-gelation and gelation processes in milk. J. Dairy Res. 72:303-310. https://doi.org/10.1017/S0022029905001020.

Falowo, A. B., F. E. Mukumbo, E. M. Idamokoro, J. M. Lorenzo, A. J. Afolayan, and V. Muchenje. 2018. Multi-functional application of Moringa oleifera Lam. in nutrition and animal food products: A review. Food Res. Int. 106:317-334. https://doi.org/10.1016/j .foodres.2017.12.079.

Fernández-Salguero, J. 2009. Proteolysis during the ripening of goats' milk cheese made with plant coagulant or calf rennet. Food Res. Int. 42:324-330. https://doi.org/10.1016/j.foodres.2008.12.009.

Galán, E., F. Prados, A. Pino, L. Tejada, and J. Fernández-Salguero. 2008. Influence of different amounts of vegetable coagulant from cardoon Cynara cardunculus and calf rennet on the proteolysis and sensory characteristics of cheeses made with sheep milk. Int. Dairy J. 18:93-98. https://doi.org/10.1016/j.idairyj.2007.06.003.

González-Rábade, N., J. A. Badillo-Corona, J. S. Aranda-Barradas, and M. C. Oliver-Salvador. 2011. Production of plant proteases in vivo and in vitro-A review. Biotechnol. Adv. 29:983-996. https:/ /doi.org/10.1016/j.biotechadv.2011.08.017.

Grappin, R., T. Rank, and N. Olson. 1985. Primary proteolysis of cheese proteins during ripening. A review. J. Dairy Sci. 68:531540. https://doi.org/10.3168/jds.S0022-0302(85)80855-9.

Hang, F., Q. Wang, Q. Hong, P. Liu, Z. Wu, Z. Liu, H. Zhang, and W. Chen. 2016. Purification and characterization of a novel milkclotting metalloproteinase from Paenibacillus spp. BD3526. Int. J. Biol. Macromol. 85:547-554. https://doi.org/10.1016/j.ijbiomac 2016.01.028.

Huang, X. W., L. J. Chen, Y. B. Luo, H. Y. Guo, and F. Z. Ren. 2011. Purification, characterization, and milk coagulating properties of ginger proteases. J. Dairy Sci. 94:2259-2269. https://doi.org/10 $.3168 /$ jds.2010-4024.

Jacob, M., D. Jaros, and H. Rohm. 2011. Recent advances in milk clotting enzymes. Int. J. Dairy Technol. 64:14-33. https://doi.org/10 $.1111 /$ j.1471-0307.2010.00633.x.

Jensen, H. B., K. S. Pedersen, L. B. Johansen, N. A. Poulsen, M. Bakman, D. E. W. Chatterton, and L. B. Larsen. 2015. Genetic variation and posttranslational modification of bovine $\kappa$-casein: Effects on caseino-macropeptide release during renneting. J. Dairy Sci. 98:747-758. https://doi.org/10.3168/jds.2014-8678.

Jiang, T., J. Chen, L. Xue, and L. S. Chen. 2007. Study on milkclotting mechanism of rennet-like enzyme from glutinous rice wine: Proteolytic property and the cleavage site on k-casein. J. Dairy Sci. 90:3126-3133. https://doi.org/10.3168/jds.2007-0118.

Keil, B. 2012. Specificity of Proteolysis. Springer Science \& Business Media.

Kethireddipalli, P., and A. R. Hill. 2015. Rennet coagulation and cheesemaking properties of thermally processed milk: Overview and recent developments. J. Agric. Food Chem. 63:9389-9403. https:/ /doi.org/10.1021/jf504167v.

Lazcano-Ramírez, H. G., A. Gómez-Felipe, D. Díaz-Ramírez, Y. Durán-Medina, L. Sánchez-Segura, S. de Folter, and N. MarschMartínez. 2018. Non-destructive plant morphometric and color analyses using an optoelectronic 3D color microscope. Front. Plant Sci. 9:1409. https://doi.org/10.3389/fpls.2018.01409.

Lee, K. D., and J. J. Warthesen. 1996. Mobile phases in reversephase HPLC for the determination of bitter peptides in cheese. J. Food Sci. 61:291-294. https://doi.org/10.1111/j.1365-2621.1996 .tb14178.x.

Leone, A., A. Spada, A. Battezzati, A. Schiraldi, J. Aristil, and S. Bertoli. 2016. Moringa oleifera seeds and oil: Characteristics and uses for human health. Int. J. Mol. Sci. 17:2141. https://doi.org/ 10.3390/ijms17122141. 
Li, Q., and Z. Zhao. 2019. Acid and rennet-induced coagulation behavior of casein micelles with modified structure. Food Chem. 291:231-238. https://doi.org/10.1016/j.foodchem.2019.04.028.

Li, Z., K. Scott, Y. Hemar, and D. Otter. 2018. Protease activity of enzyme extracts from tamarillo fruit and their specific hydrolysis of bovine caseins. Food Res. Int. 109:380-386. https://doi.org/10 $.1016 /$ j.foodres.2018.04.039.

Lufrano, D., R. Faro, P. Castanheira, G. Parisi, P. Veríssimo, S. Vairo-Cavalli, I. Simões, and C. Faro. 2012. Molecular cloning and characterization of procirsin, an active aspartic protease precursor from Cirsium vulgare (Asteraceae). Phytochemistry 81:7-18. https://doi.org/10.1016/j.phytochem.2012.05.028.

Luo, J., C. Xiao, H. Zhang, F. Ren, X. Lei, Z. Yang, and Z. Yu. 2018. Characterization and milk coagulating properties of Cynanchum otophyllum Schneid. Proteases. J. Dairy Sci. 101:2842-2850. https: //doi.org/10.3168/jds.2017-13888.

Macedo, I. Q., C. J. Faro, and E. M. Pires. 1993. Specificity and kinetics of the milk-clotting enzyme from cardoon (Cynara cardunculus L.) toward bovine K-casein. J. Agric. Food Chem. 41:1537-1540. https://doi.org/10.1021/jf00034a001.

Majumder, R., S. P. Banik, and S. Khowala. 2015. Purification and characterisation of $\kappa$-casein specific milk-clotting metalloprotease from Termitomyces clypeatus MTCC 5091. Food Chem. 173:441448. https://doi.org/10.1016/j.foodchem.2014.10.027.

McMahon, D. J., and B. S. Oommen. 2008. Supramolecular structure of the casein micelle. J. Dairy Sci. 91:1709-1721. https://doi.org/ 10.3168/jds.2007-0819.

Miettinen, A., G. Chinga-Carrasco, and M. Kataja. 2014. Three-dimensional microstructural properties of nanofibrillated cellulose films. Int. J. Mol. Sci. 15:6423-6440. https://doi.org/10.3390/ ijms15046423.

Mohamed Ahmed, I. A., E. E. Babiker, and N. Mori. 2010. pH stability and influence of salts on activity of a milk-clotting enzyme from Solanum dubium seeds and its enzymatic action on bovine caseins. Lebensm. Wiss. Technol. 43:759-764. https://doi.org/10 .1016/j.lwt.2009.12.011.

Narwal, R. K., B. Bhushan, A. Pal, A. Panwar, and S. Malhotra. 2016. Purification, physico-chemico-kinetic characterization and thermal inactivation thermodynamics of milk clotting enzyme from Bacillus subtilis MTCC 10422. Lebensm. Wiss. Technol. 65:652-660. https://doi.org/10.1016/j.lwt.2015.08.065.

Pontual, E. V., B. E. A. Carvalho, R. S. Bezerra, L. C. B. B. Coelho, T. H. Napoleão, and P. M. G. Paiva. 2012. Caseinolytic and milk-clotting activities from Moringa oleifera flowers. Food Chem. 135:1848-1854. https://doi.org/10.1016/j.foodchem.2012.06.087.

Saini, R. K., I. Sivanesan, and Y.-S. Keum. 2016. Phytochemicals of Moringa oleifera: A review of their nutritional, therapeutic and industrial significance. 3 Biotech. 6:203. https://doi.org/10.1007/ s13205-016-0526-3.

Salehi, M., M. R. Aghamaali, R. H. Sajedi, S. M. Asghari, and E. Jorjani. 2017. Purification and characterization of a milk-clotting aspartic protease from Withania coagulans fruit. Int. J. Biol. Macromol. 98:847-854. https://doi.org/10.1016/j.ijbiomac.2017.02.034.

Sandra, S., C. Cooper, M. Alexander, and M. Corredig. 2011. Coagulation properties of ultrafiltered milk retentates measured using rheology and diffusing wave spectroscopy. Food Res. Int. 44:951-956. https://doi.org/10.1016/j.foodres.2011.02.018.

Santiago-López, L., J. E. Aguilar-Toalá, A. Hernández-Mendoza, B. Vallejo-Cordoba, A. M. Liceaga, and A. F. González-Córdova.
2018. Invited review: Bioactive compounds produced during cheese ripening and health effects associated with aged cheese consumption. J. Dairy Sci. 101:3742-3757. https://doi.org/10.3168/jds .2017-13465.

Shah, M. A., S. A. Mir, and M. A. Paray. 2014. Plant proteases as milk-clotting enzymes in cheese making: A review. Dairy Sci. Technol. 94:5-16. https://doi.org/10.1007/s13594-013-0144-3.

Simpson, D. J. 2001. Proteolytic degradation of cereal prolamins-the problem with proline. Plant Sci. 161:825-838. https://doi.org/10 .1016/S0168-9452(01)00482-4.

Sousa, M. J., and F. X. Malcata. 1998. Proteolysis of ovine and caprine caseins in solution by enzymatic extracts from flower of Cynara cardunculus. Enzyme Microb. Technol. 22:305-314. https://doi .org/10.1016/S0141-0229(97)00173-7.

Szewińska, J., J. Siminska, and W. Bielawski. 2016. The roles of cysteine proteases and phytocystatins in development and germination of cereal seeds. J. Plant Physiol. 207:10-21. https://doi.org/ 10.1016/j.jplph.2016.09.008.

Uniacke-Lowe, T., F. Chevalier, S. Hem, P. F. Fox, and D. M. Mulvihill. 2013. Proteomic comparison of equine and bovine milks on renneting. J. Agric. Food Chem. 61:2839-2850. https://doi.org/10 $.1021 /$ jf3045846.

Vishwanatha, K. S., A. G. Appu Rao, and S. A. Singh. 2010. Production and characterization of a milk-clotting enzyme from Aspergillus oryzae MTCC 5341. Appl. Microbiol. Biotechnol. 85:18491859. https://doi.org/10.1007/s00253-009-2197-z.

Wang, X., L. He, Q. Zhao, H. Chen, Y. Shi, J. Fan, Y. Chen, and A. Huang. 2021. Protein function analysis of germinated Moringa oleifera seeds, and purification and characterization of their milkclotting peptidase. Int. J. Biol. Macromol. 171:539-549. https:// doi.org/10.1016/j.ijbiomac.2021.01.026.

Wang, X., Y. Shi, Y. Chen, J. Fan, Y. Pu, and A. Huang. 2020. Comparative proteome analysis of matured dry and germinating Moringa oleifera seeds provides insights into protease activity during germination. Food Res. Int. 136:109332. https://doi.org/10.1016/ j.foodres.2020.109332.

Yegin, S., M. Fernandez-Lahore, A. J. Gama-Salgado, U. Guvenc, Y. Goksungur, and C. Tari. 2011. Aspartic proteinases from Mucor spp. in cheese manufacturing. Appl. Microbiol. Biotechnol. 89:949960. https://doi.org/10.1007/s00253-010-3020-6.

Zhang, Y., H. Wang, L. Tao, and A. Huang. 2015. Milk-clotting mechanism of Dregea sinensis Hemsl. protease. J. Dairy Sci. 98:84458453. https://doi.org/10.3168/jds.2015-9851.

Zhang, Y., Y. Xia, X. Liu, Z. Xiong, S. Wang, N. Zhang, and L. Ai. 2019. High-level expression and substrate-binding region modification of a novel BL312 milk-clotting enzyme to enhance the ratio of milk-clotting activity to proteolytic activity. J. Agric. Food Chem. 67:13684-13693. https://doi.org/10.1021/acs.jafc.9b06114.

\section{ORCIDS}

Xuefeng Wang @ https://orcid.org/0000-0001-8175-8478 Qiong Zhao ๑ https://orcid.org/0000-0002-0011-2980

Aixiang Huang @ https://orcid.org/0000-0003-4148-8455 